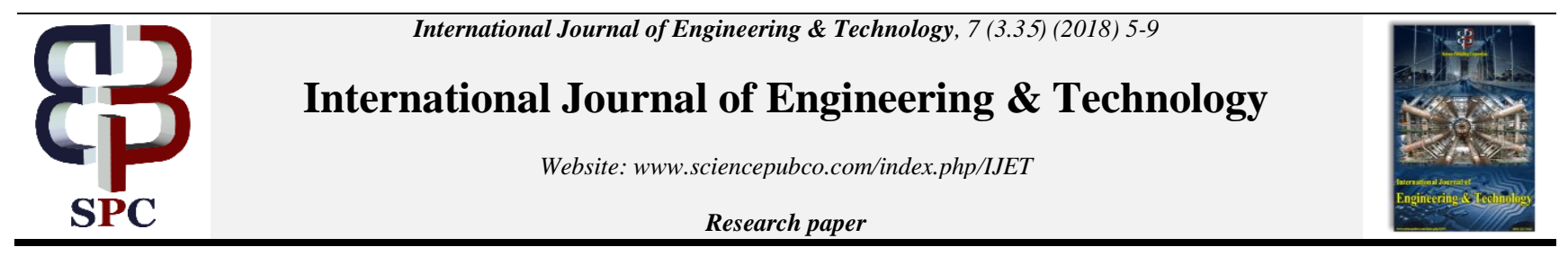

\title{
Numerical Investigation on Flexural Beams Made with Metakaolin and Shredded Plastic Waste
}

\author{
M.Sivaraj $^{{ }^{*}}$, Dr. R. Sundararajan ${ }^{2}$, K.Vivek $^{3}$ and Dr. T. Senthil Vadivel ${ }^{4}$ \\ ${ }^{I}$ Research Scholar, ${ }^{2}$ Registrar, Department of Civil Engineering, Karpagam Academy of Higher Education, Coimbatore \\ ${ }^{3}$ Assistant Professor, Department of Civil Engineering, Paavai Engineering College, Namakkal \\ ${ }^{4}$ Professor \& Head, Department of Civil Engineering, School of Engineering \& Technology, Adamas University, \\ *Email: tsnsenthu@ rediffmail.com
}

\begin{abstract}
Among various building materials, concrete is the most widely used conventional material. Nowadays many scientists are on a hunt for a substitute material for constructionthat is eco-friendly and made from industrial waste products and offer sustainable development. In this study, cement was partially substituted by metakaolin of varying percentage as $0 \%, 2.5 \%, 5 \%, 7.5 \%$ and $10 \%$ by weight of cement. Shredded plastic waste of $0.5 \%$ by weight was added to concrete by replacing coarse aggregate in the concrete. M20 grade concrete is used for beams. Optimum replacement percentage of metakaolin was determined from the tests. Ultimate load carrying capacity of beams produced with the optimum replacement percentage was compared with the numerical investigation done by finite element modelling package ANSYS 12.0.
\end{abstract}

Keyword: Metakaolin, Shredded Plastic Waste, Flexural beams, Finite element modeling

\section{Introduction}

According to the increase in population, production and utilization of Portland cement is not only costly and energy intensive but also releases a significant amount of carbon dioxide content into the environment. In recent days, metakaolin is one of the pozzolanic material which has cementitious properties and is used to produce high strength concrete. The binding capacity or free lime content present in metakaolin decides its scale of purity. Metakaolin was partially replaced with cement in percentages ranging from $0 \%, 2.5 \%$, $5 \%, 7.5 \%$ and $10 \%$ by weight of cement.

Growing population also creates a global problem byincreased generation of waste, and it must be taken into consideration in order to solve the world's resource and energy challenges. Increasing consumers around the world produce various types of non-decaying or non-biodegradable waste materials, resulting in disposal crisis. Disposal of waste plastic materials in environment results in a lot of pollution and damage to the natural ecosystem and climatic conditions. Utilization of plastic waste in concrete will be a useful alternate solution to the waste disposal problems. In this study, $0.5 \%$ of shredded plastic waste was added with the concrete by replacing the coarse aggregate.

\section{Literatures Reviewed}

Aiswarya et al. (2013) made a review on the use of metakaolin in concrete and concluded that the replacement of metakaolin in concrete showed better results in strength and durability aspects and made it non-porous. Rakesh Kumar (2014) found that the utilization of metakaolin in concrete would act as flexible particulate filler in concrete and improves its fracture and toughness. Raju and Rajiv Chauhan (2014) conducted an experimental study on the strength behavior of cement concrete with use of plastic fibers and concluded that no cracks were found and smooth surface finish with $1 \%$ of plastic fiber by weight which results the decrease in compression and tensile strength .Murali and Surthee (2012) studied the concrete with metakaolin as partial replacement of cement and decided that $7.5 \%$ of metakaolin increased the strength parameters when compared with $5 \%$ and $10 \%$ of metakaolin. Pawar et al. (2016) analyzed three models of reinforced beams in ANSYS 15 modeling to determine the effect of percentages of steel reinforced in flexural behavior. Finite element models of RC models were analyzed in nonlinear FEM analysis, and the flexural responses were considered up to failure.

\section{Materials Used}

In this study, the following materials were used in the preparation of M20 grade concrete.The materials conformed o various Indian codes such as IS 12269:1987, IS 383:1970 for cement and aggregates respectively. Mix design was done as per the codal guidelines given in IS 10262:2009.

- Ordinary Portland Cement - 53 Grade

- Standard consistency $-29 \%$

- Fineness $-6.07 \%$

- $\quad$ Fine aggregate - Zone II

$\circ \quad$ Bulking of sand $-1.17 \%$

$\circ \quad$ Specific gravity -2.53

○ Fineness modulus -3.29

- $\quad$ Coarse aggregate $-20 \mathrm{~mm}$ 
- Specific gravity -2.79

- Fineness modulus -3.51

- Crushing strength $-15.96 \%$

- $\quad$ Super plasticizer - CONPLAST SP430

○ Dosage $-2.5 \%$
- Metakaolin - It is mainly composed of Silica (53\%)and Alumina (43\%), the chemical composition of the metakaolin was described in the figure 1.

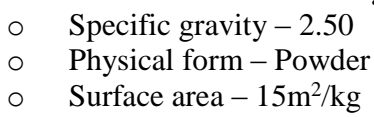

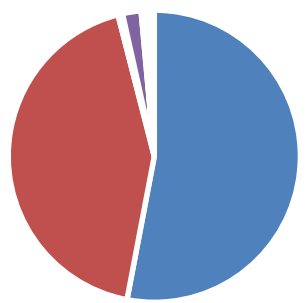

$-\mathrm{SiO} 2-\mathrm{A} 2 \mathrm{O} 3-\mathrm{Fe} 2 \mathrm{O} 3-\mathrm{TiO} 2-\mathrm{SO} 4-\mathrm{CaO}-\mathrm{MgO}-\mathrm{Na} 2 \mathrm{O}-\mathrm{K} 2 \mathrm{O}-\mathrm{L}$.O.I $-\mathrm{P} 2 \mathrm{O} 5$

Figure 1: Chemical composition of Metakaolin

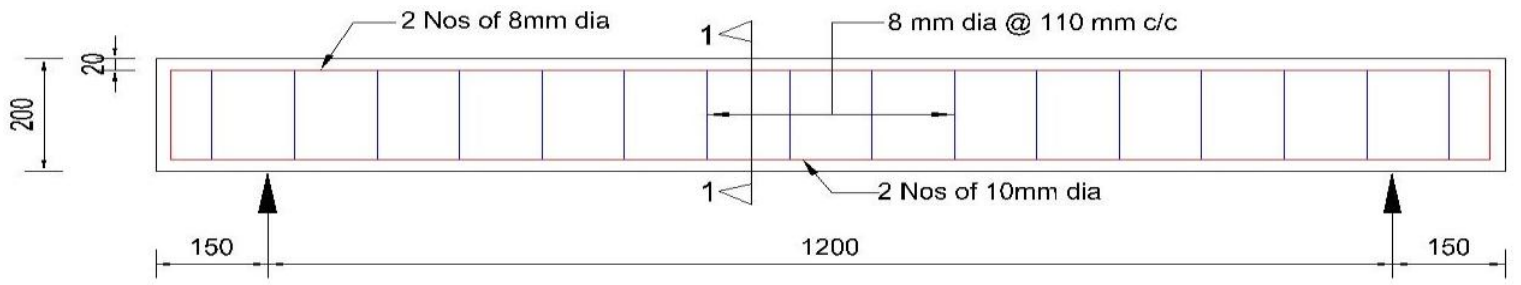

LONGITUDINAL SECTION

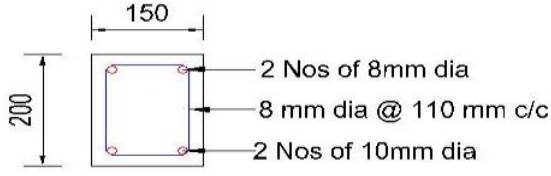

SECTION ON "1-1"

Figure 2: Reinforcement details of RC flexural beam

- $\quad$ Shredded plastic waste -Theyarecrushed,foreign matters removed and then heated under temperature and crushed down to the required size of aggregates.

$$
\begin{array}{ll}
\circ & \text { Specific gravity }-0.95 \\
\circ & \text { Crushing value }-2.5 \% \\
\circ & \text { Density }-0.90 \mathrm{~g} / \mathrm{cc}
\end{array}
$$

Table 1: Mix design for M20 grade

\begin{tabular}{|c|c|c|c|c|}
\hline Materials & Cement & $\begin{array}{c}\text { Fine } \\
\text { aggregate }\end{array}$ & $\begin{array}{c}\text { Coarse } \\
\text { aggregate }\end{array}$ & Water \\
\hline Weight in kg & 352 & 800 & 1155 & 158.40 \\
\hline Proportion & 1 & 2.27 & 3.28 & 0.45 \\
\hline
\end{tabular}

Table 2: Properties of fresh concrete at $0.45 \mathrm{w} / \mathrm{c}$ ratio

\begin{tabular}{|c|c|c|c|c|c|}
\hline \multirow{2}{*}{ Test } & \multicolumn{5}{|c|}{ Mix ID } \\
\cline { 2 - 6 } & $\mathbf{N M C}$ & $\mathbf{M P}_{\mathbf{1}}$ & $\mathbf{M P}_{\mathbf{2}}$ & $\mathbf{M P}_{\mathbf{3}}$ & $\mathbf{M P}_{\mathbf{4}}$ \\
\hline Slump value (mm) & 58 & 65 & 78 & 89 & 100 \\
\hline Compaction factor & 0.90 & 0.91 & 0.94 & 0.96 & 0.92 \\
\hline
\end{tabular}

\section{Strength Characteristics}

The strength characteristics of M20 grade concrete with varying percentage of metakaolin in addition with $0.5 \%$ of shredded plastic waste were tested by casting cubes, cylinders, prisms and beams. The specimens were allowed for the curing periods of 7, 14, 28, 56 and 90 days in water.
Table 3: Compressive strength test results

\begin{tabular}{|c|c|c|c|c|c|}
\hline \multirow{2}{*}{ Mix ID } & \multicolumn{5}{|c|}{ Average Compressive Strength $\left(\mathbf{N} / \mathbf{m m}^{2}\right)$} \\
\cline { 2 - 6 } & $\mathbf{7}$ days & 14 days & $\mathbf{2 8}$ days & $\mathbf{5 6}$ days & 90 days \\
\hline NMC & 18.64 & 19.73 & 28.00 & 32.72 & 37.26 \\
\hline $\mathrm{MP}_{1}$ & 19.58 & 20.91 & 29.20 & 33.15 & 38.46 \\
\hline $\mathrm{MP}_{2}$ & 19.79 & 21.58 & 31.72 & 34.60 & 39.87 \\
\hline $\mathbf{M P}_{3}$ & $\mathbf{2 0 . 9 1}$ & $\mathbf{2 2 . 6 0}$ & $\mathbf{3 2 . 9 6}$ & $\mathbf{3 6 . 3 7}$ & $\mathbf{4 2 . 1 9}$ \\
\hline $\mathrm{MP}_{4}$ & 19.63 & 21.34 & 31.18 & 34.37 & 39.08 \\
\hline
\end{tabular}

Table 4: Split tensile strength test results

\begin{tabular}{|c|c|c|c|c|c|}
\hline \multirow{2}{*}{ Mix ID } & \multicolumn{5}{|c|}{ Average Split tensile Strength $\left(\mathbf{N} / \mathbf{m m}^{2}\right)$} \\
\cline { 2 - 6 } & $\mathbf{7}$ days & $\mathbf{1 4}$ days & $\mathbf{2 8}$ days & $\mathbf{5 6}$ days & 90 days \\
\hline $\mathrm{NMC}$ & 1.46 & 1.92 & 3.17 & 3.37 & 3.46 \\
\hline $\mathrm{MP}_{1}$ & 1.50 & 1.98 & 3.32 & 3.45 & 3.54 \\
\hline $\mathrm{MP}_{2}$ & 1.53 & 2.08 & 3.36 & 3.49 & 3.63 \\
\hline $\mathrm{MP}_{3}$ & $\mathbf{1 . 5 7}$ & $\mathbf{2 . 0 9}$ & $\mathbf{3 . 4 5}$ & $\mathbf{3 . 5 6}$ & $\mathbf{3 . 7 1}$ \\
\hline $\mathrm{MP}_{4}$ & 1.52 & 2.00 & 3.34 & 3.46 & 3.58 \\
\hline
\end{tabular}

Table 5: Flexural strength test results

\begin{tabular}{|c|c|c|c|c|c|}
\hline \multirow{2}{*}{ Mix ID } & \multicolumn{5}{|c|}{ Average Flexural Strength $\left(\mathbf{N} / \mathbf{m m}^{2}\right.$ ) } \\
\cline { 2 - 6 } & $\mathbf{7}$ days & 14 days & $\mathbf{2 8}$ days & $\mathbf{5 6}$ days & 90 days \\
\hline $\mathrm{NMC}$ & 2.85 & 3.78 & 6.29 & 6.47 & 6.77 \\
\hline $\mathrm{MP}_{1}$ & 2.98 & 3.95 & 6.58 & 6.77 & 7.008 \\
\hline $\mathrm{MP}_{2}$ & 3.01 & 4.09 & 6.65 & 6.84 & 7.16 \\
\hline $\mathrm{MP}_{3}$ & $\mathbf{3 . 1 2}$ & $\mathbf{4 . 1 4}$ & $\mathbf{6 . 8 9}$ & $\mathbf{7 . 0 8}$ & $\mathbf{7 . 4 1}$ \\
\hline $\mathrm{MP}_{4}$ & 2.99 & 3.97 & 6.61 & 6.79 & 7.12 \\
\hline
\end{tabular}


Based on the obtained results, Mix ID $\mathrm{MP}_{3}$ (Metakaolin $7.5 \%$ With $0.5 \%$ of Shredded Plastic Waste) was considered as the optimum replacement percentage of metakaolin for improving the strength of concrete with the addition of $0.5 \%$ of shredded plastic waste. For this mix proportion, RC flexural beams were cast with the dimension 150 x $200 \times 1500 \mathrm{~mm}$. Reinforcement details provided in the flexural beam are mentioned in figure 2 . The beams were tested under two-point loading at $\mathrm{L} / 3$ distance from both the supports.

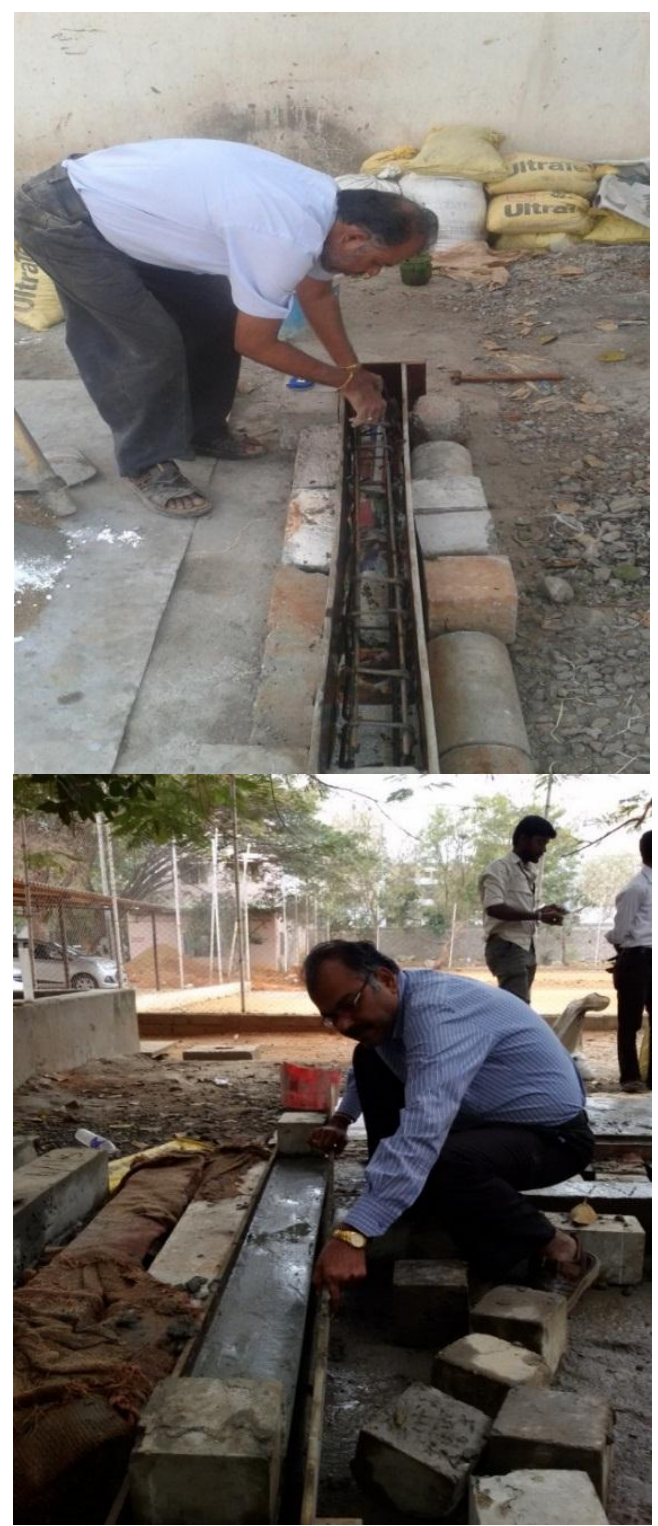

Figure 3: Preparation of Reinforced concrete beams

\section{Finite Element Modeling}

Finite element analysis on the reinforced concrete beams were done by the software package ANSYS 12.0. The beams were modeled and tested either in APDL or GUI. The specimens were loaded under twopoint loading conditions and non-linear buckling analysis was done to determine the characteristic of the sections. The correlation was done by comparing the predicted analytical results in ANSYS and with the experimental results. The following elements were adopted for material idealization.
Table 6: Description of used elements in ANSYS

\begin{tabular}{|c|c|c|c|c|}
\hline \multirow[b]{2}{*}{ Beam Components } & \multirow{2}{*}{$\begin{array}{c}\text { Elements } \\
\text { used from } \\
\text { ANSYS } \\
\text { library }\end{array}$} & \multicolumn{3}{|c|}{ Element Characteristics } \\
\hline & & $\begin{array}{l}\text { Number } \\
\text { of nodes }\end{array}$ & $\begin{array}{l}\text { Type of } \\
\text { element }\end{array}$ & $\begin{array}{c}\text { DOF } \\
\text { per } \\
\text { node }\end{array}$ \\
\hline Concrete & SOLID65 & 8 & $\begin{array}{c}\text { Brick } \\
\text { element }\end{array}$ & $3-\mathrm{T}^{*}$ \\
\hline $\begin{array}{l}\text { Bearing steel plate } \\
\text { of loading }\end{array}$ & SOLID45 & 8 & $\begin{array}{c}\text { Brick } \\
\text { element }\end{array}$ & $3-\mathrm{T}^{*}$ \\
\hline $\begin{array}{l}\text { Steel reinforcing } \\
\text { bars }\end{array}$ & LINK8 & 2 & $\begin{array}{l}\text { Discrete } \\
\text { element }\end{array}$ & $3-\mathrm{T}^{*}$ \\
\hline
\end{tabular}

$\mathrm{T}^{*}$ - Translational Degree of Freedom; R** - Rotational Degrees of Freedom

Modeling a structural element for the behavior of flexural members made with partial replacement of cement and gravel by metakaolin and shredded plastic waste respectivelywas a difficult task. The properties of concrete were found based on the guidelines of IS456:2000.

Table 7: Material properties assigned for SOLID65 element

\begin{tabular}{|c|l|c|}
\hline S. No. & \multicolumn{1}{|c|}{ Definition } & Value \\
\hline 1 & Young's modulus of elasticity & $25491 \mathrm{MPa}$ \\
\hline 2 & Poisson's ratio & 0.24 \\
\hline 3 & Characteristic compressive strength & $20 \mathrm{MPa}$ \\
\hline 4 & Density & $2410 \mathrm{~kg} / \mathrm{m}^{3}$ \\
\hline 5 & $\begin{array}{l}\text { Ultimate compressive \& tensile } \\
\text { strength }\end{array}$ & $32.96 \mathrm{MPa} \& 3.45 \mathrm{MPa}$ \\
\hline 6 & Shear transfer parameter & 0.2 to 0.7 \\
\hline
\end{tabular}

Table 8: Material properties assigned for SOLID45 element

\begin{tabular}{|c|l|c|}
\hline S. No. & \multicolumn{1}{|c|}{ Definition } & Value \\
\hline 1 & Young's modulus of elasticity & $2.1 \times 10^{5} \mathrm{MPa}$ \\
\hline 2 & Poisson's ratio & 0.3 \\
\hline
\end{tabular}

Table 9: Material properties assigned for LINK8 element

\begin{tabular}{|c|l|c|}
\hline S. No. & \multicolumn{1}{|c|}{ Definition } & Value \\
\hline 1 & Young's modulus of elasticity & $2.1 \times 10^{5} \mathrm{MPa}$ \\
\hline 2 & Poisson's ratio & 0.3 \\
\hline 3 & Yield stress & $415 \mathrm{MPa}$ \\
\hline
\end{tabular}

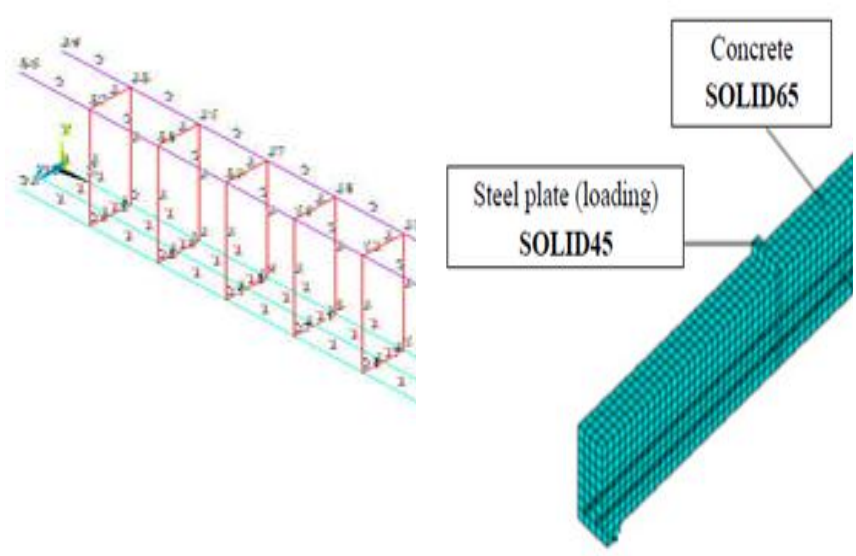

Figure 4: Reinforcement details in ANSYS

Figure 5: Element types used in ANSYS

\section{Experimental Investigation}

All the beams were cast for the Mix ID $-\mathrm{MP}_{3}$ and the water-cement ratio of 0.45 . The beam specimens were cured for 28 days and then tested. The size of beam cast was $150 \times 200 \times 1500 \mathrm{~mm}$, two numbers of $10 \mathrm{~mm} \& 8 \mathrm{~mm}$ diameter rods were at bottom and top. 


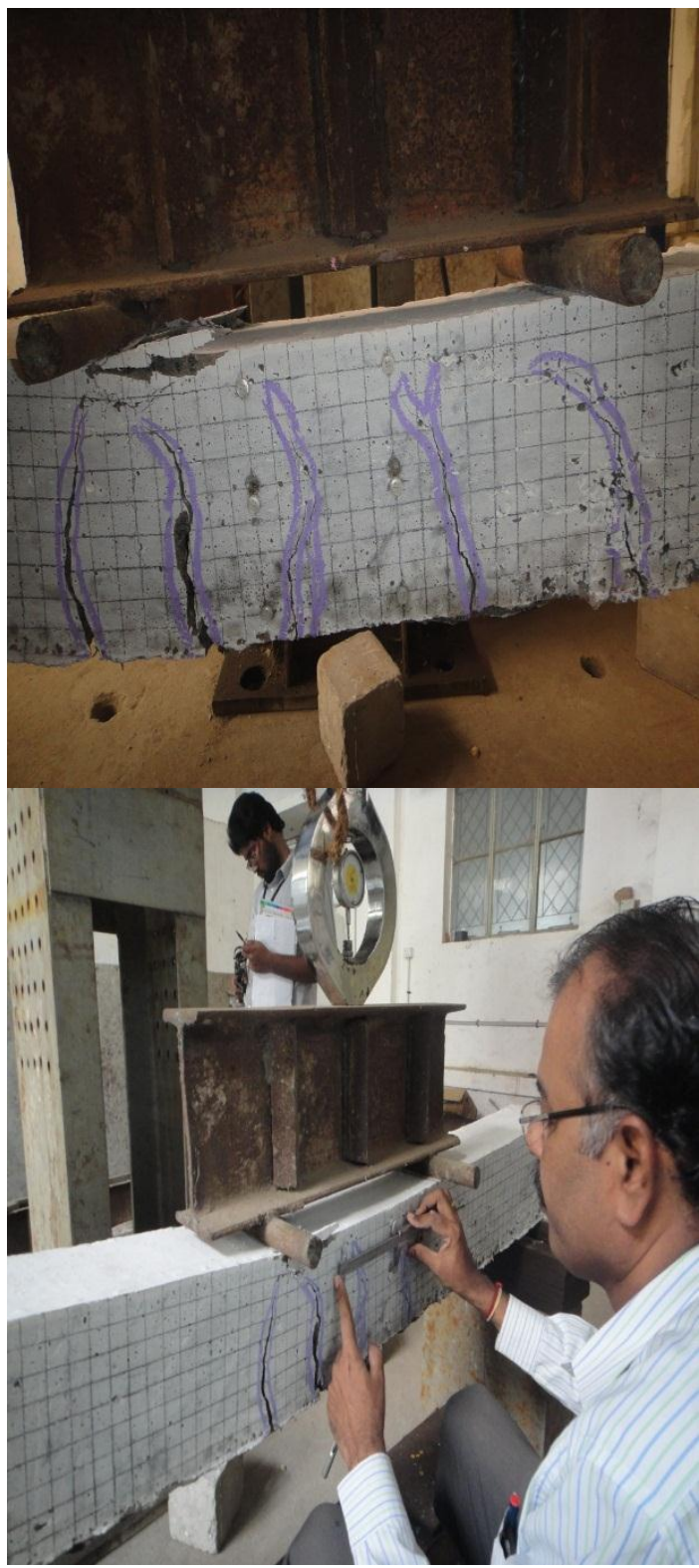

Figure 6: Experimental test setup

\section{Comparison of Results}

The results of experimental investigation was compared with the finite element model made with ANSYS and the results are tabulated below:

Table 10: Comparison of Ultimate load carrying capacity and Midspan Deflection

\begin{tabular}{|c|c|c|c|c|c|c|c|}
\hline $\begin{array}{l}\text { S. } \\
\text { N }\end{array}$ & $\begin{array}{c}\mathbf{M i} \\
\mathbf{x}\end{array}$ & \multicolumn{3}{|c|}{$\begin{array}{c}\text { Ultimate load carrying } \\
\text { capacity }(\mathbf{k N})\end{array}$} & \multicolumn{3}{|c|}{ Midspan Deflection (mm) } \\
\hline $\mathbf{o}$ & ID & $\begin{array}{c}\text { Experim } \\
\text { ental }\end{array}$ & $\begin{array}{c}\text { Numer } \\
\text { ical }\end{array}$ & $\begin{array}{c}P_{\text {Exp }} / \mathbf{P} \\
\text { FEA }\end{array}$ & $\begin{array}{c}\text { Experim } \\
\text { ental }\end{array}$ & $\begin{array}{c}\text { Numer } \\
\text { ical }\end{array}$ & $\begin{array}{c}\Delta_{\text {Exp }} / \Delta \\
\text { FEA }\end{array}$ \\
\hline 1 & $\begin{array}{l}\mathrm{N} \\
\mathrm{M} \\
\mathrm{C}\end{array}$ & 28.67 & 32 & 0.90 & 10.197 & 12.14 & 0.84 \\
\hline 2 & $\begin{array}{c}\text { MP } \\
3\end{array}$ & 33.33 & 38 & 0.88 & 7.936 & 8.53 & 0.93 \\
\hline
\end{tabular}

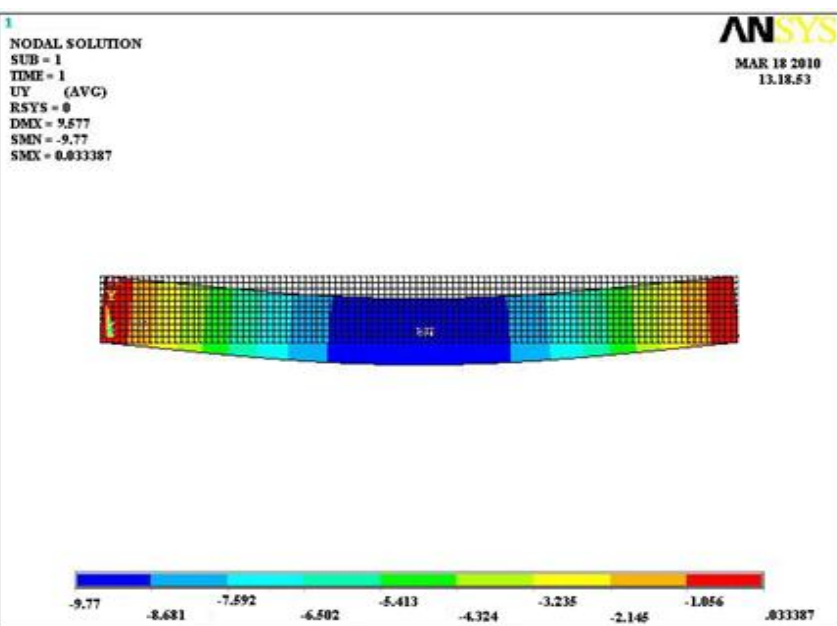

Figure 7: Deflection behavior of Flexural beam NMC

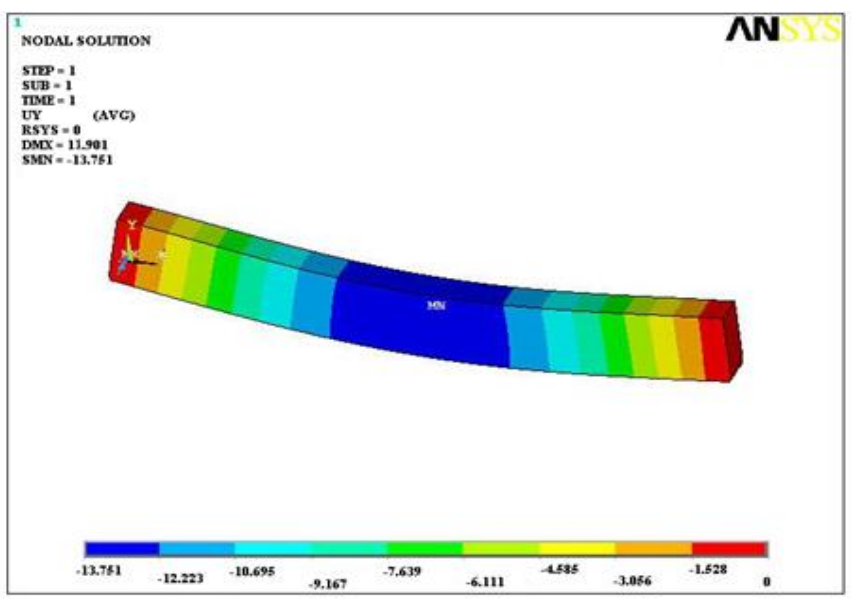

Figure 8: Deflection behavior of Flexural beam $\mathrm{MP}_{3}$

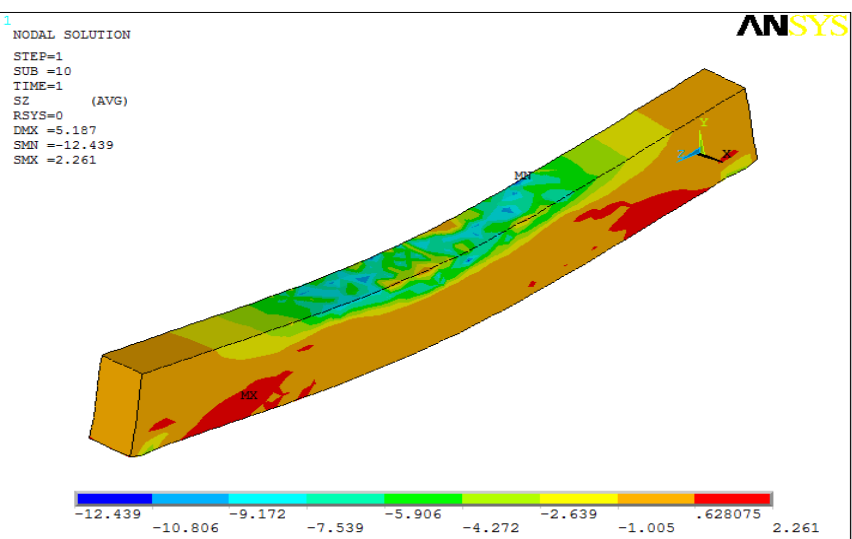

Figure 9: Stress contour for Flexural beam NMC

\section{Conclusions}

Following are the conclusions made after the investigation on flexural beams made with metakaolin and shredded plastic waste as partial replacement materials for cement and coarse aggregate.

- The admixtures like metakaolin and $0.5 \%$ shredded plastic waste used at optimum quantity tends to increase the strength of the concrete mix when compared with conventional concrete. 
- $7.5 \%$ of metakaolin $+0.5 \%$ of shredded plastic waste increases the Compressive Strength, Split Tensile Strength and Flexural strength of concrete at curing periods of 7, 14, 28,56 and 90 days. Increase of $7.5 \%$ of metakaolin increases the strength drastically.

- Numerical analysis results mostly coincide with the experimental results.

- The initial cracking does not affect failure load.

- There is no sudden failure of concrete and failure is gradual due to yielding of steel which is preferred for safety mode of failure.

- Numerical analysis shows ultimate load carrying capacity of $14.01 \%$ improved results compared to experimental results.

\section{References}

[1] Smarzewski, Piotr (2016). Numerical solution of reinforcedconcrete beam using arc-length method, Biuletyn WAT, Vol.LXV, Nr 1.

[2] P. Muthupriya ,Dr.K.Subramanian\& Dr.B.G.Vishnuram, "Investigation on Behaviour of High Performance Reinforced concrete columns with metakaolin and fly ash as admixture "- March 2011 International journal of advanced Engineering Technology, Vol.11 , No.1., Pages 190-202

[3] Raju \& Rajiv Chauhan, "An experimental study on strength behavior of cement concrete with use of plastic fibre"- March 2014 International journal of Engineering Research \& Applications , Pages 30-34

[4] Ankur.A.Patel., Deepa.A.Sinha (2011)., "An Experimental Investication On The Effect Of Flyash And Metakaolin On Steel Fibre Reinforced Concrete At Temperature At $20^{\circ}$ C", Proceeding Of The National Conference On "Recent Trends In Engineering And Technology", 13-14th May Organized By BVM Engineering Collage, Vallabh,vidhyanagar-388120.Dist. Anand. (Gujarat), Paper Id-101067

[5] Sallam H.E., Badawy A.A., and El-Emam H. M. (2013). Numerical Simulation of the Performance of Strengthened RC Beams Using Smeared Crack Approach, Journal of Jazan University-Applied Sciences Branch, Vol.2, No.2, May, (Rajab1434 H).

[6] Basu, Prabir C, et al, High Reactivity metakaolin: a new pozzolana, proceedings of the national seminar on innovative construction materials, VJTI, Mumbai, Jan 21-22. 